INTERNATIONAL JOURNAL OF RESEARCH IN SOCIAL SCIENCES \& HUMANITIES

An International Open-Access Peer Reviewed Referred Journal

\title{
EXAMINING MODELS FOR MEASURING CORPORATE GOVERNANCE TO RESOLVE FINANCIAL CRISES
}

*Jabbar Sehan Issa, **Asmaa Habib Alnasiry

*Ministry of Higher Education and Scientific Research

**Al-Farabi University College, Iraq Baghdad, Iraq

DOI: http://doi.org/10.37648/ijrssh.v12i01.005






\begin{abstract}
This document deals with corporate governance and its impact on corporate performance and economic performance. This work is first summarized and based on previous work done, for example, to provide a clearer expression of the corporate governance models of shareholders and shareholders. It then addresses some of the key factors that lead to the effectiveness of corporate governance, and examines some of the strengths, weaknesses, and economic consequences associated with different corporate governance systems. In addition to providing information not provided in previous work, it also provides new information on the concentration of ownership and voting rights in a number of OECD countries. This document also provides empirical evidence on the relationship between corporate governance, firm performance, and economic growth. Finally, several policy implications are identified. This document shows how a corporate governance framework can influence the development of stock markets, R\&D and innovative, corporate activities and the development of an active SME sector, thereby affecting economic growth. However, there is no single model of corporate governance, and each country has, over time, developed a variety of mechanisms to overcome representation problems arising from separation of ownership and control. This document examines the various mechanisms used in different systems (eg centralized ownership, executive rent schemes, stock market, inter-corporate shareholding, etc.) and examines the available evidence. Whether they have achieved their goal or not. do. For example, one of the benefits of centralized ownership is that it provides more effective oversight of management and helps with representation problems arising from separation of ownership and control. However, some costs reduce liquidity and the likelihood of risk diversification. Although dispersed ownership carries more liquidity, it may not provide the appropriate incentive to encourage the long-term relationships required for certain types of investment. Thus, one of the challenges for policymakers is how to create an appropriate corporate governance framework that can provide the benefits of controlling shareholders who act as direct observers, while ensuring that they hinder the development of markets. Are not stocks. Expropriation of excessive rents.
\end{abstract}

Keywords: government, corporate governance, financial crisis 


\section{INTRODUCTION}

Since the onset of the financial crisis, the global debate over corporate governance and information disclosure has grown dramatically. This review highlights the links between the wider wave of reform since the onset of the financial crisis and the recent corporate governance and disclosure reforms. Corporate governance failures are being investigated at every level of global financial market regulation, leading to changes in governance not only for financial institutions but also for other state-owned companies. Many jurisdictions have begun to review corporate governance laws and regulations in addition to financial oversight systems. The desire of regulators to have stronger governance standards and a stronger shareholder in corporate governance in key markets has led to significant developments, especially in terms of executive rewards and risk management, as well as shareholder rights, quality of board oversight and quality of corporate governance disclosure.

Numerous studies have shown that corporate governance (CG) practices improve organizational performance in stable economic conditions and are a shield against the adverse effects of financial crises and turbulent economic conditions. However, identifying good CG practices has historically been a challenge for policymakers. Most of the world's economies, learning from various financial and economic crises, have taken new steps and improvements to improve their CG practices. Patterns and practices that are evaluated as effective have also changed over time in response to evolving economic, social, and political challenges. These methods contribute to the sustainable growth of jobs and the economy. However, the lack of credible research in many countries and regions still hinders the implementation of $\mathrm{CG}$ reforms, which can prevent the negative effects of financial crises and uncertainty.

To manage this new state of governance, capitalist economies have developed a variety of governance systems and policymakers, taking into account the institutional contexts of their respective countries (Lee et al., 2012; McCarthy and Popper, 2003). However, many studies have examined the effects of the financial crisis on jobs in the established capitalist economy and have proposed modifications to the CG practices of these countries (Grove et al., 2011).

The structure of this article is as follows. Following this introduction, Section 2 provides a brief overview of the CG situation in Russia. Section 3 theoretical background discusses the relevant literature of the study. Section 4 describes 


\section{Volume: 12, Issue: 1, January-March 2022}

data collection and research methods, and Section 5 presents our experimental results. Finally, Section 6 concludes the paper, which identifies managerial implications and orientations for future research.

\section{THE ECONOMIC SITUATION IN IRAQ}

The Iraqi economy is heavily dependent on oil, in other words, it is based on the oil economy. About 95 percent of Iraq's total revenue comes from oil sales. Numerous wars in Iraq and long-term international sanctions have left the Iraqi economy behind.

Iraq has seen a lot of political, social and economic turmoil over the past few decades. This led to a financial crisis. Looking at the eight-year war with Iran in 1980-1988 and the consequences of the disruption and destruction of the oil industry, in addition, was the loss of oil reserves that had been violated for many years. This was followed by the invasion of Kuwait in 1990 and the heavy price of international sanctions imposed for years. These events led to a huge amount of international debt that devastated the country's once prosperous economy. Regardless of the turmoil and accidents, improving the security environment and achieving stability led to an increase in foreign and domestic investment. At the same time, the Iraqi government was able to control inflation to a record low of $6.37 \%$ in October 2009, after reaching a full-time peak of $76.55 \%$ in August 2006. Money supply was the largest cause of inflation. Gives and is statistically significant at the level of $1 \%$. Long-term estimates state that the money supply is the most important determinant of inflation in Iraq during the period 1995-2015, and is statistically as high as $1 \%$. In fact, an increase of one unit changes inflation by $59 \%$. The second important factor is import inflation. The import coefficient is positive as expected and is statistically significant. This can be explained by the fact that Iraq is a small country and depends on the import of its goods and services in order to close the gap between supply and market demand. The real exchange rate seems to have a negative sign and is statistically significant at the level of $1 \%$, which shows that the value of the Iraqi dinar has the ability to curb inflation in Iraq in the long run.

In 2012, Iraq's economic growth was set at 4.8 percent, which was projected to reach 7.8 percent in 2014. After the war that led to the overthrow of Saddam, Iraq steadily increased its oil production and became one of the largest exporters of oil, and owes a 50 percent increase in oil supply after Iraq's presence in world markets. 
Iraq, which has countless natural resources in addition to oil.

The per capita GDP for each Iraqi after the war that led to the overthrow of Saddam was $\$ 7,790$ in 2005, and this GDP per capita increased to $\$ 6,300$ in 2012 . According to information obtained from the National Bank of Qatar, it was predicted that the Iraqi economy will continue to experience high growth. At the same time, however, the possibility of civil unrest in the future was predicted, which could lead to lower oil revenues, the financial crisis in Iraq, and inflation.

In 2012, Iraq produced an average of 1.3 million barrels of oil per day, the highest level in 30 years.

However, the National Bank of Qatar had predicted that Iraq's GDP growth in 2014 would reach about 3.6 percent with an increase in oil production capacity as well as the development of government services, trade and construction.

In April 2014, it was announced that the International Monetary Fund had announced in its latest report that Iraq had the highest economic growth among Middle Eastern countries. The International Monetary Fund also said that Iraq is at the top of the region in terms of GDP growth.
THE IMPORTANCE OF THE SUBJECT

According to the research topic, the importance of the present research can be examined from two aspects:

Corporate governance: In recent years, corporate governance has become a major and dynamic aspect of business and attention to it is increasing exponentially. Progress is being made in the exercise of corporate governance globally. International organizations such as the Organization for Economic Co-operation and Development (OECD) provide acceptable international standards in this regard. In the United States, Britain, and other countries, they continue to strengthen their corporate governance systems, paying special attention to shareholders and their relationships, accountability, improving the performance of the board of directors, auditors, and accounting and internal control systems. That companies are managed and controlled by these methods. In addition, individual investors, institutional investors, accountants and auditors, and other money and capital market players are aware of the philosophy of existence and the need for continuous correction and improvement of corporate governance. The collapse of large corporations such as Enron, Wordcom, Adelphi, Ceico, etc., which caused losses to many investors and stakeholders, was 
due to weak corporate governance systems.

These issues have led to more and more emphasis on the need to promote and reform corporate governance at the international level (Hasas, Yeganeh, 1384: 30).

\section{LITERATURE REVIEW}

In general, when there is a link between financial auditing and corporate governance, the relationship that is often explored is how corporate governance variables in research on Russia, government leaders, and policymakers seek to improve the situation. The $\mathrm{CG}$ in Russia focused more on changing the internal aspects of governance mechanisms. From a theoretical point of view, such a focus on such internal aspects makes sense, because external factors are constantly changing in transition economies and are difficult to manage and respond to. Therefore, the inference of institutional theory seems to be appropriate for examining CG practices in Russia. From the perspective of institutional theory, CG functions are influenced by internal and external institutional environmental factors (Filatotchev and Nakajima, 2010; Gewons, 2013; McCarthy and Poofer, 2003). External institutional factors include economic, legal, political, social, and cultural factors, as well as the effects of secondary and peripheral stakeholders (Filatotchev and Nakajima, 2010; McCarthy and Poofer, 2003). Internal institutional environments include composition of the board, ownership structures and shareholder participation, information disclosure practices, and leadership characteristics of senior executives. These factors are influenced by key stakeholders, including directors, board of directors and shareholders (Filatotchev and Nakajima, 2010).

There are several reasons to focus on the internal mechanisms of CG. First, our study focuses on the economy in transition: Russia. Due to stormy economic conditions, economies in transition often change their institutional arrangements for economic, legal, political, and cultural reform (Chen, 2014; McCarthy and Poofer, 2003). Therefore, the study of CG practices of Russian banks in different periods focusing on the external environment does not reveal the exact impact of CG practices (Jackowicz and Kowalewski, 2013). Second, CG practices primarily target core and agent relationships and aim to reduce the selfserving behavior of internal decision makers. Previous researchers have emphasized the role of internal CG mechanisms in trying to improve the status of $\mathrm{CG}$ in transition economies (Black et al., 2012; Love et al., 2007; McCarthy and 
Poofer, 2003). Third, CG measures in Russia are still in progress. During an uncertain economic transition, the roles, responsibilities, and competencies of key stakeholders become more important in terms of better governance (Johannesson et al., 2012; McCarthy and Puffe, 2003). Fourth, our study focuses on the banks of a particular country. Therefore, to examine the relationship between $\mathrm{CG}$ performance, internal governance mechanisms in Russia seem appropriate.

\section{RESEARCH BACKGROUND}

Mongiardino and Plath (2010) show that despite increasing regulatory pressure from the financial crisis, corporate governance in large banks appears to have improved only to a limited extent. They outline the best practices of corporate governance and highlight the need for at least (1) corporate board at the board level, of which (2) the majority should be independent, and (3) the CRO should be part of the board. Be a bank However, by looking at the 20 largest banks, they find a small number of banks that follow the best practices in 2007. Even though most large banks had their own company committees, most of them rarely met. Also, most corporate committees were not composed of independent members with sufficient financial knowledge (see also Howe and Tom, 2009) and most of the large banks had CROs, but their location and reporting line did not guarantee adequate access levels. And so it affects the CEO and the board.

While the role and importance of the CRO and corporate governance in general have been highlighted in the banking industry in newspapers, in various reports (Brancato et al., 2006) as well as in pragmatic studies (e.g., Banham). , 2000), has been much neglected in academic literature so far. The only exception we are aware of is the simultaneous study of Alloo and Yaramli (2011). They examine whether a strong, independent corporate management has a significant relationship with a bank's risktaking and performance during a financial crisis in a sample of 74 major US banking holding companies. They create a Risk Management Index (RMI) based on five variables related to the bank's risk management power, including a fictitious variable whether the bank's CRO is a board member and other advocacy measures for CRO power within the bank's board. Shows that banks with high RMI values were less exposed to mortgagebacked securities in 2006, were less active in off-balance sheet derivatives transactions, had lower non-performing loan deductions, had lower downside risk, and the ratio They have higher Sharp during the crisis years of 2007/2008.

Some other aspects of corporate governance in banks, such as board 
characteristics and CEO pay, have been considered in several recent academic studies (e.g., Beltratti and Stulz, Future; Erkens et al., 2010; Fahlenbrach And Stulz, 2011; Minton et al., 2010). However, research on corporate governance and the impact of corporate governance assessment on financial firms is still very limited. In addition, financial institutions have their own characteristics, such as higher transparency, tighter regulation, and government intervention (Levin, 2004), which require a distinct analysis of corporate governance issues. Consistently, Adams and Mehran (2003) and Maki and O'Hara (2003) emphasize the importance of paying attention to governance differences between banks and non-banking institutions.

Two recent studies by Beltratti and Stulz and Fahlenbrach and Stulz (2011) analyze the impact of corporate governance on the performance of banks during the financial crisis. However, both studies rely on variables that have been used in research to analyze the relationship between corporate governance and the value of non-financial corporations. Fahlenbrach and Stulz (2011) analyze the impact of CEO incentives and stock ownership on bank performance, and there is no evidence for better bank performance in which the incentives provided by the CEO payment package are stronger (e.g. For example, equity-based compensation deductions are higher. In fact, their evidence suggests that banks provide stronger incentives for CEOs to perform worse in a crisis. A possible explanation for this finding is that CEOs may have focused on shareholder interests in creating crises and activities that the market believes are welcome. However, after the post, the unpleasant results became expensive for the banks and their shareholders. In addition, their results show that CEOs did not reduce their stock by anticipating the crisis, and CEOs did not cover their resources. Hence, their results indicate that the bank's CEOs did not anticipate the crisis and the poor performance of the banks because they themselves suffered a lot of losses.

Beltratti and Stulz examine the relationship between corporate governance and bank performance during the financial crisis in a 98 international banking sample. Most importantly, they found that banks with more stock-friendly board, as measured by the "Corporate Governance Amount" (CGQ) derived from RiskMetrics, performed worse during the crisis, indicating a common understanding. "Good governance" is not necessarily in the interests of shareholders. Beltratti and Stulz argue that "banks that were pressured by the board to maximize shareholder wealth created risks that were perceived to 
create shareholder wealth, but then the results were costly because "It was not expected when it was in danger."

Erkens et al. (2010) used an international sample of 296 financial firms from 30 countries to examine the relationship between corporate governance and the performance of financial firms during the 2007/2008 financial crisis. According to Beltratti and Stulz, they found that companies with more independent boards and higher institutional ownership experienced worse stock returns during the crisis. They argue that companies with higher institutional ownership take more risks before the crisis, leading to more shareholder losses during the crisis. In addition, companies with more independent boards raised more capital during the crisis, which led to the transfer of wealth from current shareholders to shareholders. Minton et al. (2010) examine how US banks' risk-taking and performance in crisis are related to board independence and board financial expertise. Their results show that the financial expertise of the board of directors has a positive relationship with the bank's risk-taking and performance before the crisis, but it has a negative relationship with the bank's performance in the crisis. Finally, Cornet et al. (2010) examined the relationship between different corporate governance mechanisms and the performance of banks in crisis in a sample of approximately 300 US commercial banks. Vs. Erkens et al. (2010), Beltratti and Stulz, and Fahlenbrach and Stulz (2011), they find better corporate governance, e.g., a more independent board, a higher sensitivity to performance, and increased internal ownership, positively related to crisis performance.

\section{ANALYTICAL FRAMEWORK : CORPORATE GOVERNANCE MODELS}

Corporate governance has traditionally been associated with the problem of "principal representative" or "agency". The "principal representative" relationship occurs when the person who owns a business is not the same as the person who runs or controls it. For example, investors (top managers) hire managers (agents) to run the company on their behalf. Investors need the special human capital of managers to generate their return on investment, and managers may need investor funding because they may not have enough capital to invest. In this case, there is a separation between financing and management of the company, that is, there is a separation between ownership and control.

Before examining the relationship between corporate governance, corporate performance and economic growth, it is 
useful to have a framework that can be used to understand how corporate governance can affect corporate behavior and economic performance. One of the problems with the current debate about corporate governance is that there are different and often conflicting views about the nature and purpose of the company. This discussion ranges from positive issues related to the actual operation of institutions to normative issues related to the company's goals. Therefore, to understand this discussion, it is useful to consider the various analytical contexts or approaches that are often used.

The term corporate governance has been used in many different ways and the boundaries of the subject are very different. In the discussion of economics about the impact of corporate governance on performance, there are basically two different models of the company, the shareholder model and the stock acceptor model. Corporate governance in its strict sense (shareholder model) describes the formal system of senior management accountability to shareholders. In its broadest sense (stakeholder model), corporate governance can be used to describe the formal and informal network of corporate relationships. More recently, the shareholder approach emphasizes shareholder participation, which can contribute to the firm's long-term performance and shareholder value, and the shareholder approach also recognizes that business ethics and shareholder relationships can also enhance the firm's long-term credibility and success. The two models are not as intense as they first seem, but rather an issue of emphasis.

Disagreement over the definition of corporate governance is also reflected in the discussion of governance reform. This disagreement leads to completely different analyzes of the issue and completely different solutions offered by the participants in the reform process. Therefore, having a clear understanding of the different models can provide insight and help us to examine this discussion from different angles. Understanding the issues involved can also provide a basis for identifying good corporate governance practices and providing policy advice.

\section{Stakeholder Model}

According to the shareholder model, the company's goal is to maximize shareholder wealth through allocation, production and dynamic efficiency, ie the company's goal is to maximize profits. Performance evaluation criteria in this model can be simply considered as the market value (ie shareholder value) of the company. Therefore, managers have an implicit obligation to ensure that firms are run for the benefit of shareholders. The basic 
problem of corporate governance in this model arises from the relationship between the CEO and the principal resulting from the separation of beneficial ownership and executive decisions. It is this separation that makes the company's behavior far from the ideal of profit maximization. This is because the main interests and goals (investors) and the representative (managers) when separated from ownership and control are different. Because managers do not own the company, they do not bear all their costs or enjoy their full benefits. Thus, although investors are interested in maximizing shareholder value, managers may have other goals, such as maximizing their pay, growing market share, or joining specific investment projects.

The main factor problem is also a key element of the "incomplete contracts" view of the company developed by Coase (1937), Jensen and Meckling (1976), Fama and Jensen (1983a, b), Williamson (1975, 1985), Agion and Bolton. (1992) and Hart (1995). This is because if it is possible to write a "full contract", the main agent will not have a problem. In this case, the investor and the manager only sign a contract that specifies what the manager does with the funds, how the dividend is distributed, and so on. In other words, investors can use a contract to fully align the interests and goals of managers with their own goals. However, complete contracts are impossible, because it is impossible to predict or describe all possible future cases. This incompleteness of contracts means that investors and managers must allocate some kind of "residual control rights" if the residual control rights do not have the right to decide in unforeseen circumstances or conditions that the contract includes. Thus, as Hart (1995) states: "Governance structures can be seen as decision-making mechanisms not specified in the original contract."

So why don't investors just write a contract that gives them all the remaining control rights in the company, meaning that the owners have to decide what to do in a situation where the contract does not include them? In principle, this is not possible, because the reason why owners hire managers in the first place is that they need the special human capital of managers to run the company and generate the return on their investments. Thus, the problem of "representation" is also an asymmetric information problem, meaning that managers are better informed about which are the best alternatives to investor funds. As a result, the manager is arbitrarily selected with significant control and authority to allocate funds. This authority may have limitations in the contract, but the fact is that most managers 
have the remaining control rights. The fact that managers have the most control rights can lead to problems of confinement of management and rent extraction by managers. Thus, most corporate governance deals with the limitations of managers' authority and accountability, for example Demb and Neubauer (1992) state that "corporate governance is a matter of accountability to performance."

One of the economic consequences of the possibility of managers taking ownership of rents by mail (or opportunistic behavior) is that it reduces the amount of resources that investors are willing to provide in advance to finance the company, a problem that is generally more Known as the maintenance issue, it has been widely discussed in the literature, see Williamson (1975, 1985) and Klein, Crawford, \& Alchian (1978). A major consequence of opportunistic behavior is that it leads to inefficient social levels of investment, which in turn can have a direct impact on economic growth. According to the shareholder model, therefore, corporate governance primarily seeks to find ways to align the interests of managers with investors, by ensuring the flow of foreign funds to firms and the return of investors.

An effective corporate governance framework can minimize agency costs and maintenance problems associated with separation of ownership and control. In general, there are three types of mechanisms that can be used to align the interests and goals of managers with shareholders and overcome management problems and management oversight:

- One method tries to persuade managers to implement efficient management that directly matches the interests of managers with shareholders. Executive compensation programs, stock options, direct oversight by the board and so on.

- Another method involves strengthening the rights of shareholders so shareholders are both more motivated and have the ability to oversee management. This method increases the rights of investors through the legal protection of expropriation by managers. Protection and enforcement of shareholder rights, domestic trade bans, etc.

- Another method is to use indirect means of corporate control, such as those offered by capital markets, managerial labor markets, and markets for corporate control.

One of the criticisms of the company's shareholder model is the implicit assumption that differences between strong and well-established managers and shareholders are weak and scattered. This has led to an almost unique focus, both in analytical work and in reform, on solving 
surveillance and management problems, which are among the main problems of corporate governance in the area of dispersed ownership. For example, much of this work addresses concerns about the role of the board, stock options and executive rewards, shareholder support, the role of institutional investors, strengthening management and market effectiveness for acquisitions, and so on.

The fact is that the most widely used company, assumed in the original work of Berle and Means (1932), is not a rule but an exception. Instead, the dominant organizational form for the company is a centralized ownership. One of the reasons we see the concentration of ownership may be due in part to lack of investor support. However, unlike a public company in which the directors have most of the remaining control rights with very few shareholders, the close control company is usually controlled by a majority shareholder or by a group of shareholders. This could be an individual or family, or shareholders such as financial institutions, or other companies operating through a holding company or mutual shareholders.

Another reason for the prevalence of centralized ownership as much as the dominant form of organization is that it is one way to solve the problem of supervision. According to the main operating model, due to differences in the interests and goals of managers and shareholders, the separation of ownership and control is expected to have detrimental effects on the performance of companies. Therefore, one way to overcome this problem is direct control of shareholders through centralized ownership. The problem with dispersed ownership is that management oversight incentives are weak. Shareholders have an incentive to "ride freely" in the hope that other shareholders will monitor. This is because the benefits of oversight are shared with all stakeholders, while all costs of oversight are borne by those who oversee. These free riding problems do not arise with centralized ownership, as the major shareholder derives most of the benefits of their regulatory efforts.

Therefore, for a corporation that is kept close, the issue of corporate governance is not primarily about shareholder protection or oversight issues. Instead, the problem is more with equity, holding companies, and pyramids or other mechanisms that dominant shareholders use to exercise control, often at the expense of minority investors. It is the support of minority shareholders that is crucial in this case. One of the issues raised in this regard is how policymakers make reforms that do not exclude shareholders' voting rights while protecting the interests of minority 
shareholders. In other words, how do we make reforms that maintain the benefits of centralized ownership control but at the same time encourage the flow of foreign funds to companies and, in turn, should reduce ownership concentration?

Another critique of the shareholders' approach is that the analytical focus on how to solve the corporate governance problem is very limited. Shareholders' approach to corporate governance is primarily concerned with aligning the interests of managers and shareholders and ensuring the flow of foreign capital to firms. However, shareholders are not the only ones investing in the company. The competitiveness and ultimate success of a company is the result of teamwork involving a wide range of sourcing suppliers, including investors, employees, creditors, suppliers, distributors and customers. Corporate governance and economic performance will be affected by the relationships of these different shareholders in the company. According to this argument, any assessment of the strengths, weaknesses, and economic implications of different corporate governance frameworks requires a broader analytical framework that includes incentives and incentives to avoid confrontation with all stakeholders.

\section{Stakeholder Model}

The stakeholder model has a broader view of the company. According to the traditional shareholder model, the company is responsible for a wider constituency of non-shareholder shareholders. Other stakeholders may include contract partners such as employees, suppliers, customers, creditors and community members such as members of the community in which the company is based, environmental interests, local and national governments, and the community as a whole. This view holds that large corporations should be "socially responsible" institutions that are managed in the public interest. According to this model, a wider constituency interested in employment, market share, and the growth of business relationships with suppliers and buyers, as well as financial performance, is evaluated.

The problem with the company's traditional stakeholder model is that it is difficult, if not impossible, to ensure that companies achieve these broader goals. Blair (1995) argues against this view: to ensure that companies meet their social obligations. As a result of these shortcomings, few academics, policymakers, or other proponents of corporate governance reform still support this model. 
However, given the potential implications of corporate governance for economic performance, the notion that companies are accountable to parties other than shareholders is questionable. What is important is the impact that different stakeholders can have on the company's behavior and performance and economic growth. Any assessment of the effects of corporate governance on economic performance must consider the incentives that all participants who potentially contribute to the firm's performance face. With this in mind, the stakeholder model has recently been redefined, emphasizing a more precise definition of stakeholders. Thus, the "new" shareholder model specifically defines stakeholders as those actors who have contributed to their own assets, see Blair (1995). This redefinition of the shareholder model is also consistent with the transaction costs and incomplete contract theories of the firm in which the firm can be seen as a "contractual relationship", see Coase (1937), Williamson (1975, 1985), Jensen And McLean (1976), and Aoki, Gustafson, and Williamson (1990).

The "best" companies According to the "new" stakeholder model, companies are committed to suppliers, customers and employees. Therefore, this new shareholder approach is a natural extension of the shareholder model. For example, whenever a company needs specific investments, the company's performance will depend on various sources of human and physical capital. It often happens that the company's ultimate competition and success is the result of teamwork involving a wide range of suppliers from a variety of sources, including investors, employees, creditors and suppliers. Therefore, it is in the interest of stakeholders to consider other stakeholders and to develop longterm relationships, foster trust and commitment among different stakeholders (see Mayer, 1996). Corporate governance in this area becomes a problem to find mechanisms that obtain specific investments from different stakeholders and encourage active cooperation between shareholders in creating wealth, jobs and sustainability of appropriate enterprises, according to the principles See OECD. Corporate Governance (OECD 1999a).

However, whenever the contract is incomplete and certain investments are made, opportunistic behavior and delayed problems arise. As discussed earlier, one consequence of opportunistic behavior is that it generally leads to low investment. The main relationship between the representative and the shareholder model is discussed is just one of the many areas in which it occurs. Low investment in the shareholder model includes investment by employees, suppliers, and so on. For 
example, employees may be reluctant to invest in a particular human capital if they are unable to contribute to the return on their investment, but have to bear the costs. By making those investments, companies may otherwise be reluctant to spend resources on staff training, and employees may no longer be able to reap the benefits if they increase their human capital and choose to leave. Distributors and distributors may also not invest in company-specific investments such as custom components, distribution networks, etc. In this broader context, corporate governance becomes a problem to find a mechanism that reduces the scope of expropriation and opportunism and leads to more efficient levels. Investment and resource allocation.

According to the stakeholder model, corporate governance is primarily concerned with the fact that different systems of governance are effective in promoting investment and long-term commitment among different stakeholders, see Williamson (1985). For example, Kaster (1992) stated that the problem of governance is the creation of special systems for incentives, safeguards, and dispute resolution processes that help maintain effective business relationships in the presence of the opportunist. Blair (1995) also defines corporate governance more broadly in this context, arguing that corporate governance should be considered as a set of institutional arrangements for managing relationships between all stakeholders who provide companyspecific assets.

One criticism of the stakeholder model, or the fear of participants in the reform process, is that managers or managers may use "shareholder" reasons to justify the company's poor performance. The advantage of the shareholder model is that it provides clear guidance in assisting managers in setting priorities and establishing a mechanism for measuring the performance of the corporate management team, ie corporate profitability. On the other hand, the advantage of the shareholder model is its emphasis on overcoming the low investment problems associated with opportunistic behavior and encouraging active cooperation among stakeholders to ensure the long-term profitability of the company.

One of the most challenging tasks on the reform agenda is how to develop corporate governance frameworks and mechanisms that extract efficient levels of investment from all stakeholders. However, it is difficult to identify the frameworks and mechanisms that enhance the efficient level of investment, while maintaining the accountability aspects of the performance 
provided by the shareholder model. At the very least, this means that mechanisms that enhance investment and stakeholder cooperation must be adopted in conjunction with mechanisms to prevent management confinement. Stakeholder goals should not be used to prevent clear guidance on how to set company goals and priorities. How the company achieves these goals and how to determine performance oversight should also be clearly defined.

\section{CONCLUSION}

Corporate governance affects the development and performance of capital markets and has a great impact on resource allocation. In the period of increasing capital mobility and globalization, this has also become an important condition that affects the industrial competition and the economy of the member countries. This article aims to further develop our understanding of corporate governance and its impact on corporate performance and economic performance. By doing so, it identifies some of the key factors that increase the efficiency of corporate governance and examines some of the strengths, weaknesses, and economic consequences associated with different corporate governance systems. This paper also provides a review of empirical evidence on the relationship between corporate governance, firm performance, and economic growth, highlighting areas in which there seems to be a consensus view in the literature and areas where further research is needed.

One of the obvious differences between countries' corporate governance systems is the difference in ownership and control of companies that exists across countries. There is a trade-off between concentration of ownership and concentration of voting power. Corporate governance systems can be divided according to the degree of ownership and control and the identity of the controlling shareholders. In "foreign" systems (especially the United States and the United Kingdom) for corporate governance, the fundamental conflict of interest between powerful executives and shareholders is scattered. On the other hand, in "insider" systems (especially continental Europe and Japan), the fundamental conflict between shareholder control (or block shareholders) and minority shareholders is weak.

There is no single model of good corporate governance, and both internal and external systems have different strengths, weaknesses, and economic consequences. In addition, the effectiveness of different corporate governance systems is affected by differences in the legal and regulatory frameworks of countries and historical and cultural factors, in addition to the structure 


\section{Volume: 12, Issue: 1, January-March 2022}

of product and invoice markets. Corporate governance mechanisms and their effectiveness also vary depending on the industry and the type of production activity. For example, in industries characterized by high asset quality (such as many high-tech industries), monitoring is more difficult and different mechanisms may be needed to improve company performance. It is difficult to discern what constitutes good corporate governance and under what circumstances. Therefore, the challenge is not only to identify strengths and weaknesses in each system or group of systems, but also to determine the basic conditions on which these strengths and weaknesses depend.

The benefits of centralized ownership are that it provides more effective oversight of management and helps overcome agency problems. However, the costs associated with centralized ownership are low liquidity and diverse opportunities to reduce risk. Mutual ownership brings with it higher liquidity, which can be critical to the development of innovative activities. On the other hand, it does not encourage the long-term commitment and relationship that may be required for certain types of investments. For example, when large companies are owned and controlled by each other, this can reduce transaction costs and the incentive to engage in opportunistic behaviors. So shareholders are more motivated to invest in a particular investment. On the other hand, it can also reduce the level of competition in the product market. 


\section{Volume: 12, Issue: 1, January-March 2022}

\section{REFERENCES}

1- Adams, R. and Mehran, H. (2012), "Bank board structure and performance: evidence for large bank holding companies", Journal of Financial Intermediation, Vol. 21 No. 2, pp. 243-267.

2- Adams, R.B., Mehran, H., 2003. Is corporate governance different for bank holding companies? Federal Reserve Bank of New York Economic Policy Review 9, 123142.

3- Aghion, P. and J. Bolton (1992), “An incomplete contracts approach to financial contracting", Review of Economic Studies, 59, pp. 473-494.

4- Aoki, M., B. Gustaffson and O. Williamson (1990), The Firm as a Nexus of Treaties, Sage Publications, London.

5- Australia: Productivity Commission Inquiry”. Report No. 49, 19 December.

6- Australian Government Productivity Commission (2009a). "Executive Remuneration in

7- Banham, R., 2000. Top cops of risk. CFO 16, 91-98.

8- Basel Committee on Banking Supervision, June 2008. Principles for sound liquidity risk management and supervision.

9- Beltratti, A. and Stulz, R. (2012), “The credit crisis around the globe: why some banks perform better Journal of Financial Economics, Vol. 105, pp. 1-17.

10-Beltratti, A., Stulz, R.M., forthcoming. The credit crisis around the globe: Why did some banks perform better during the credit crisis? Journal of Financial Economics.

11-Berle, A. and G. Means (1932), The modern corporation and private property, MacMillan, New York.

12-Berle, A. and G. Means (1932), The modern corporation and private property, MacMillan, New York.

13- Black, B., Carvalho, A. and Gorga, E. (2012), "What matters and for which firms for corporate governance in emerging markets? Evidence from Brazil and other BRIC countries”, Journal of Corporate Finance, Vol. 18, pp. 934-952.

14- Black, B., Carvalho, A. and Gorga, E. (2012), "What matters and for which firms for corporate governance in emerging markets? Evidence from Brazil and other BRIC countries", Journal of Corporate Finance, Vol. 18, pp. 934-952.

15-Blair, M. (1995), Ownership and control: rethinking corporate governance for the twenty-first century, Brookings Institution, Washington DC. 


\section{Volume: 12, Issue: 1, January-March 2022}

16- Boards. CCGG, Toronto, Canada, March.

17- Brancato, C., Tonello, M., Hexter, E., Newman, K.R., 2006. The role of US corporate boards in enterprise risk management, The Conference Board Research Report No. R1390-06-RR.

18-Canadian Coalition for Good Governance (CCGG) (2010). Building High Performance

19- Coase, R. H. (1937), “The nature of the firm”, Economica, 4, pp. 386-405.

20- Coase, R. H. (1937), “The nature of the firm”, Economica, 4, pp. 386-405.

21-Cornett, M.M., McNutt, J.J., Tehranian, H., 2010. The financial crisis, internal corporate governance, and the performance of publicly-traded US bank holding companies. Working Paper, Boston College.

22- Demb, A. and F. F. Neubauer (1992), The corporate board: confronting the paradoxes, Oxford University Press, Oxford.

23-Ellul, A., Yerramilli, V., 2011. Stronger risk controls, lower risk: evidence from US bank holding companies. Working Paper, Indiana University.

24- Erkens, D., Hung, M. and Matos, P. (2012), “Corporate governance in the 2007-2008 financial crisis:

25-Erkens, D., Hung, M., Matos, P., 2010. Corporate governance in the 2007-2008 financial crisis: evidence from financial institutions worldwide. Working Paper, University of Southern California.

26- evidence from financial institutions worldwide", Journal of Corporate Finance, Vol. 18 No. 2,pp. 389-411.

27-Fahlenbrach, R., Stulz, R.M., 2011. Bank CEO incentives and the credit crisis. Journal of Financial Economics 99, 11-26.

28- Fama, E. and M. Jensen (1983a), "Separation of ownership and control", Journal of Law and Economics 26, pp. 301-325.

29- Filatotchev, I. and Nakajima, C. (2010), "Internal and external corporate governance: an interface between an organization and its environment", British Journal of Management, Vol. 21 No. 1, pp. 591-606.

30-Financial Services Authority (FSA), December 2008. Strengthening liquidity standards.

31-Givens, D. (2013), "Defining governance matters: a factor analytic assessment of governance institutions", Journal of Comparative Economics, Vol. 41 No. 4, pp. 1026-1053. 


\section{Volume: 12, Issue: 1, January-March 2022}

32- Government of India, Press Information Bureau (2009). "Companies Bill, 2009 introduced

33- Grossman, S. and O. Hart (1986), "The costs and benefits of ownership: A theory of vertical and lateral integration”, Journal of Political Economy, 94, pp. 691-719.

34- Grove, H., Patelli, L., Victoravich, L. and Xu, P. (2011), "Corporate governance and performance in the wake of financial crisis: evidence from US commercial banks", Corporate Governance: An International Review, Vol. 19 No. 5, pp. 418-436.

35-Gupta, K., Krishnamurti, C. and Tourani-Rad, A. (2013), "Is corporate governance relevant during the financial crisis?", Journal of International Financial Markets, Institutions \& Money, Vol. 23 No. 1, pp. 85-110.

36- Hart, O. (1995), Firms, contracts, and financial structure, Oxford University Press, Oxford.

37-Hau, H., Thum, M.P., 2009. Subprime crisis and the board (in-)competence: private vs. public banks in Germany. Economic Policy 24, 701-751.

38- Hossain, M., Jain, P. and Mitra, S. (2013), "State ownership and bank equity in the Asia-Pacific region”, Pacific-Basin Finance Journal, Vol. 21 No. 1, pp. 914-931.

39- in Lok Sabha", Press Release, 3 August.

40-Institute of International Finance (IIF), March 2007. Principles of liquidity risk management.

41- Iwasaki, I. (2014), "Global financial crisis, corporate governance and firm survival: the Russian experience", Journal of Comparative Economics, Vol. 42 No. 1, pp. 178211.

42- Jackowicz, K. and Kowalewski, O. (2013), “Crisis, internal governance mechanisms and pension fund performance: evidence from Poland", Emerging Markets Review, Vol. 13 No. 4, pp. 493-515.

43- Jensen, M. and W. Meckling (1976), "Theory of the firm: managerial behaviour, agency costs and ownership structure", Journal of Financial Economics, 3, pp. 305360.

44- Johannesson, J., Palona, I., Guillen, J. and Fock, M. (2012), “UK, Russia, Kazakhstan and Cyprus governance compared”, Corporate Governance, Vol. 12 No. 2, pp. 226242.

45-Kester, C. W. (1992), "Industrial groups as systems of contractual governance", Oxford Review of Economic Policy, 8(3), pp. 24-44. 


\section{Volume: 12, Issue: 1, January-March 2022}

46-Klein, B., R. G. Crawford and A. A. Alchian (1978), "Vertical integration, appropriable rents and the competitive contracting process", Journal of Law and Economics, 21(2), pp. 297-326.

47-Levine, R., 2004. The corporate governance of banks: a concise discussion of concepts and evidence. World Bank Policy Research Working Paper No. 3404.

48- Li, W., Chen, C. and French, J. (2012), “The relationship between liquidity, corporate governance, and firm valuation: evidence from Russia”, Emerging Markets Review, Vol. 13 No. 4, pp. 465-477.

49- Macey, J.R., O’Hara, M., 2003. The corporate governance of banks. Federal Reserve Bank of New York Economic Policy Review 9, 91-107.

50- Mayer, C. (1996), “Corporate governance, competition and performance”, OECD Economic Studies, 27, pp. 7-34.

51-McCarthy, D. and Puffer, S. (2003), "Corporate governance in Russia: a framework for analysis", Journal of World Business, Vol. 38 No. 4, pp. 397-415.

52- McCarthy, D. and Puffer, S. (2003), "Corporate governance in Russia: a framework for analysis", Journal of World Business, Vol. 38 No. 4, pp. 397-415.

53-Minton, B., Taillard, J.P.A., Williamson, R., 2010. Do independence and financial expertise of the board matter for risk taking and performance? Working Paper, Ohio State University.

54- Mongiardino, A., Plath, C., 2010. Risk governance at large banks: have any lessons been learned? Journal of Risk Management in Financial Institutions 3, 116-123.

55-Muravyev, A., Berezinets, I. and Ilina, Y. (2014), “The structure of corporate boards and private benefits of control: evidence from the Russian stock exchange", International Review of Financial Analysis, Vol. 34 No. 3, pp. 247-261.

56- OECD (1999a), OECD Principles of Corporate Governance, Paris.

57-Sabato, G., 2010. Financial crisis: where did risk management fail? International Review of Applied Financial Issues and Economics 2, 12-18.

58-Shahwan, T.M. (2015), "The effects of corporate governance on financial performance and financial distress: evidence from Egypt", Corporate Governance, Vol. 15 No. 5, pp. 641-662.

59- Walker, D., 2009. A review of corporate governance in UK banks and other financial industry entities - Final Recommendations, London. 


\section{Volume: 12, Issue: 1, January-March 2022}

60- Wang, W., Lu, W. and Lin, Y. (2012), "Does corporate governance play an important role in BHC performance? Evidence from the US", Economic Modeling, Vol. 29 No. 3, pp. 741-760.

61- Williamson, O. E. (1975), Markets and hierarchies, MacMillan, New York.

62-Williamson, O. E. (1985), The economic institutions of capitalism, The Free Press, New York.

63- Yeh, Y., Shu, P. and Chiang, T. (2014), “Affiliation and professionalism: alternative perspectives on decomposing the board structures of financial institutions", International Review of Economics and Finance, Vol. 32 No. 1, pp. 159-174. 